\title{
MÉTODO DO “BIOGRAFEMA" E OBJETOS POÉTICOS DA MEMÓRIA DE VALE VERDE EM WEBSITE: INVESTIGAÇÕES SOBRE “O DESTINO DAS IMAGENS".
}

\author{
AUTOR: HEICTOR MIRANDA CRUZ \\ CO-AUTOR/ORIENTADOR: CINARA DE ARAUJO SOARES
}

Resumo: O plano de trabalho desenvolvido tomou o conceito de "destino das imagens", elaborado por Jacques Rancière (2012), como fundamento teórico investigativo. A construção sobre as "comunidades vaga-lume", de Didi Huberman, complementa o lugar conceitual. Os teóricos analisam as imagens e seu destino tanto no âmbito da obra de arte quanto na esfera política. A pesquisa norteadora, "Poema, experiência, Comunidade", investiga o "biografema", a imagem, a imagem em movimento, a tipografia e a escrita, como uma forma de viver poética e política, na comunidade de Vale Verde (Sul da Bahia). Trata-se de uma pesquisa poético-conceitual com os elementos estéticos da formação de comunidades. A parte prática, constituída de edição e criação de materiais de design e edição editorial (física e digital), foi inicialmente realizada em ateliê coletivo na região, com a participação de artistas, pesquisadores, estudantes e comunidade. Depois da pandemia, enfatizamos os espaços teóricos e a utilização dos arquivos gerados anteriormente na pesquisa (2016 a 2019).

Palavras-chave: Destino das imagens, Biografema, Comunidades vaga-lume. 